Int. Arch. Allergy 1955;6:195-196

\title{
President's Address
}

It is my great pleasure and privilege, Ladies and Gentlemen, to welcome you to the Ciba Foundation here in London, for this the First Symposium of our College.

I am sure you will agree that we should first express our sincere and grateful thanks to the Trustees of the Ciba Foundation, through the Director Dr. Wolstenholme, for their generosity in granting us the use of these most elegant conference rooms, and for the courtesy and lavish hospitality with which we have been received. Thank you very much, Dr. Wolstenholme. At this stage, Ladies and Gentlemen, I think I can do no better than to read to you the proposed Constitution of our Collegium - which, after revision by the Council, will be presented for your consideration, together with the Bye-Laws, at the Annual General Business Meeting at the end of the week.

But before I do so, there is another matter which I should mention, Gentlemen, particularly as it is one of which many of you may be unaware - namely that the undoubted original founder of our Collegium was Paul Kallós of Helsingborg.

The Constitution, Article 1 - The Collegium shall be called the Collegium Internationale Allergologicum. And perhaps I might explain -for the benefit of any others here like myself who have not had the advantages of a classical education - that though these Latin words may sound a trifle cumbrous to our ears, it was felt that the use of this classic tongue best conveyed the truly international character of our Collegium.

Article 2 - The objects of the Collegium shall be the study of scientific and clinical problems in allergy and related fields of medicine and these objects shall be attained by means of international co-operation and by the organisation of meetings and symposia.

Article 3 - Membership of the Collegium shall be obtainable only by invitation but the number of members from each of the participating countries shall not exceed 12.

Article 4 - When a Member reaches the age of 70 he shall be appointed Corresponding Member and he retains all the rights and privileges of ordinary membership but his place becomes available for the election of another Member from the same country.

Article 5 - The administration of the Collegium shall be based upon the right of the youngest member to rank with his senior colleague, upon the equal voice of the smallest nation and of the greatest in the management of the Collegium, and upon the spirit of goodwill and goodfellowship.

Article 6 - The sole purpose of the Collegium shall be the advancement of the study of allergy and the promotion of friendly co-operation and closer professional relationships between all workers who are guided by the humble spirit of true scientific enquiry.

Well, Gentlemen, I think that is about all, before I formally open our scientific programme. Oh, there is one last point which I should perhaps mention, since it is one that may puzzle many of you - I know it puzzled me for quite a while - and that is how I come to be occupying the Presidential Chair of this most distinguished company. When the early organisers decided to select a President they naturally wanted to pick the best man for the job; but it soon became evident that it was going to be an impossible task to select the best man among you, Gentlemen. 
And when this impasse was reached, I think one of the younger members - probably remembering the card-playing days of his student youth and a certain "misère" hand in which the player with the lowest number of points won the round - made the suggestion "Why not choose the most lowly amongst us to be President!” And the members rose to their feet and said with one voice - "Harley is the man!" And so, Gentlemen, until there presents himself someone more unworthy of the honour of the Presidential Chair, here sit I.

I have to declare that the First Symposium of the Collegium Internationale Allergologicum is now open.

D. Harley. 